\title{
Sea Turtles at Serrana Island and Serranilla Island, Seaflower Biosphere Reserve, Colombian Caribbean
}

\author{
Cristian Ramirez-Gallego ${ }^{1 *}$ and Karla G. Barrientos-Muñoz ${ }^{1,2}$ \\ ${ }^{1}$ Fundación Tortugas del Mar, Envigado, Colombia, ${ }^{2}$ Wider Caribbean Sea Turtle Conservation Network Colombia, Envigado, \\ Colombia
}

Keywords: sea turtles, loggerhead turtle (Caretta caretta), green turtle (Chelonia mydas), hawksbill turtle (Eretmochelys imbricata), distribution and abundance, nests, conservation

\section{BACKGROUND}

OPEN ACCESS

Edited by:

Sonia Bejarano,

Leibniz Centre for Tropical Marine

Research (LG), Germany

Reviewed by:

Dalia C. Barragán-Barrera,

University of Los Andes, Colombia

Roldan A. Valverde,

Southeastern Louisiana University,

United States

*Correspondence:

Cristian Ramirez-Gallego

ramirezgallego.cristian@gmail.com

Specialty section:

This article was submitted to

Marine Conservation and

Sustainability,

a section of the journal

Frontiers in Marine Science

Received: 26 May 2019

Accepted: 17 December 2019

Published: 22 January 2020

Citation:

Ramirez-Gallego $C$ and

Barrientos-Muñoz KG (2020) Sea

Turtles at Serrana Island and Serranilla Island, Seaflower Biosphere Reserve,

Colombian Caribbean

Front. Mar. Sci. 6:817.

doi: 10.3389/fmars.2019.00817
In Colombia, there are five of the seven living species of sea turtles, all of them under some risk of extinction (Morales-Betancourt et al., 2015). Of these, four species are in the Colombian Caribbean and three in the SeaFlower Biosphere Reserve (SFBR). Particularly, the green turtle (Chelonia mydas), hawksbill turtle (Eretmochelys imbricata), and loggerhead turtle (Caretta caretta) have been reported at Serrana Island (McCormick, 1997, 1998). It is likely that these three species of turtles allowed to the Spanish Captain Pedro Serrano to survive on Serrana Island from his shipwreck in 1526 to 1534, when he was rescued from this island. Some turtles were as big and larger than the largest "adargas" (oval or heart shaped leather shield), and others such as "rodelas" (round and small shield), and "broqueles" (small defensive shield), so that there were all sizes. Thanks to sea turtles, Pedro Serrano had a house and food. The enormous turtle shells served as a den and rainwater collection, eggs and meat as a source of protein, and blood to prevent dehydration (Garcilaso de la Vega, 1609). More recently, during coral reef surveys Bruckner (2012) documented the hawksbill and loggerhead turtles around Serranilla Island, and a couple green turtles mating at Bajo Nuevo. The SFBR was declared in 2000 by UNESCO, has an approximate area of $180,000 \mathrm{~km}^{2}$ and covers the extension of the department of Colombia, Archipelago of San Andres, Providencia, and Santa Catalina (CORALINA-INVEMAR., 2012). However, since 1998 no studies have been conducted on sea turtles in this area ignoring the current status of these species. Due to this lack of knowledge, initiatives that assess the sea turtle populations in the SFBR, become highly relevant to contribute to the current conservation efforts in the Caribbean. This work provides novel information on the distribution and abundance of sea turtles, as well as identification of sea turtle species in foraging areas around of Serrana and Serranilla islands-the northernmost area of the Colombian Caribbean-during Seaflower Scientific Expeditions 2016 and 2017.

\section{DATA DESCRIPTION}

\section{Study Site and Methods}

We conducted an analysis of the nesting ecology of the sea turtles in Cayo Serrana Island $(14.38333 \mathrm{~N},-80.2 \mathrm{~W})$ and Cayo Serranilla Island $(15.83333 \mathrm{~N},-79.83333 \mathrm{~W})$, within the Seaflower Scientific Expeditions 2016 and 2017, respectively, in order to assess the distribution and abundance of sea turtle species (Figure 1). Furthermore, identification and hand-capture of sea turtle species in foraging areas around of both islands were carried out. 


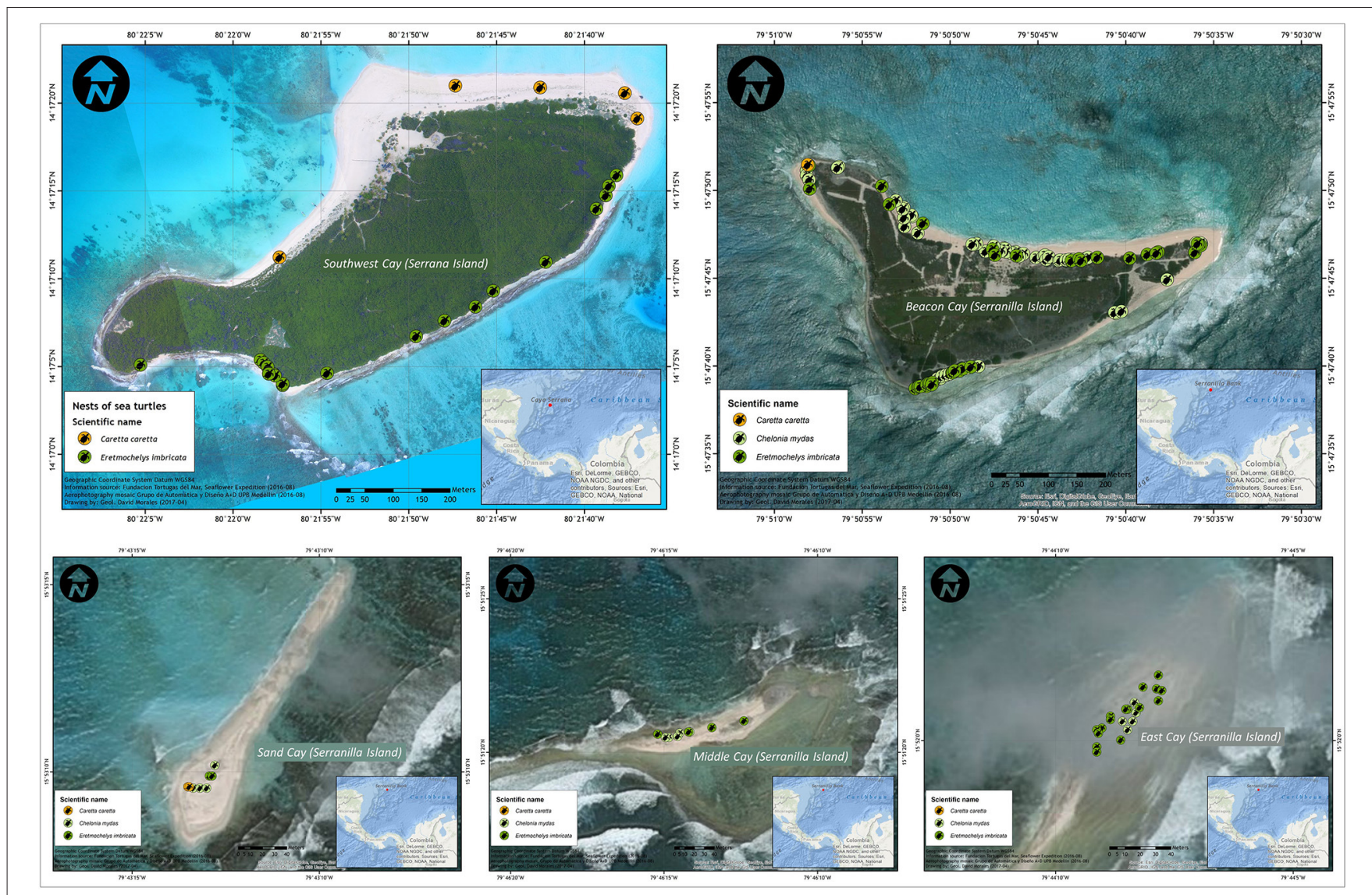

FIGURE 1 | Spatial distribution of sea turtle nests per species in Southwest Cay (Serrana Island, 2016) and Beacon Cay, Sand Cay, Middle Cay, and East Cay (Serranilla Island, 2017) in the Colombian Caribbean. Sea turtle species included Caretta caretta, Chelonia mydas, and Eretmochelys imbricata.

\section{Nesting Activity}

Systematic diurnal and nocturnal sea turtle monitoring in the beaches of Southwest Cay $(14.28913 \mathrm{~N},-80.36180 \mathrm{~W})$ with $1,661 \mathrm{~m}$ length of coastline (Diaz and Andrade, 2011) located in Serrana Island (8 days: 9-16 August, 2016) and, Beacon Cay $(15.79636 \mathrm{~N},-79.84686 \mathrm{~W})$ with $1822.79 \mathrm{~m}$ length of coastline (González and Pardo, 2017) located in Serranilla Island (24 days: 6-29 September, 2017) (Figure 1), were conducted in both areas in order to intercept nesting females, and identify clutches and hatchlings. During both periods, we patrolled the beaches at night (20:00-04:00), and all turtles encountered were tagged and measured, and all nesting events were recorded. Early in the morning (6:00-7:00) and in the afternoon (17:0018:00), we counted tracks to account for turtles that were missed the previous night, verified successful nesting events (Figures 2a-c) and found hatched nests (Figure 2d). The records of nesting activity in Sand Cay $(15.88616 \mathrm{~N},-79.72022 \mathrm{~W})$ with $205 \mathrm{~m}$ length of coastline, East Cay $(15.86689 \mathrm{~N},-79.73565 \mathrm{~W})$ with $516 \mathrm{~m}$ length of coastline, and Middle Cay $(15.85573 \mathrm{~N}$, $-79.77069 \mathrm{~W}$ ) with $331 \mathrm{~m}$ length of coastline (González and Pardo, 2017), all three located in Serranilla Island (Figure 1), were carried out in a single beach survey, on September 13, 2017 (12:00-17:00) through the registration and photographic documentation of tracks, nests, and hatchlings. All hatchlings found alive within nests or trapped between roots or rocks were released in the early morning or evening in the company of members of the Expedition and of National Navy Armada República Colombia.

\section{Description of the Dataset}

This dataset compiles the lists of sea turtle species in its different life stages, nests, nesting females, and individuals-juveniles or adults-sighted or captured in-water, recorded during the Seaflower Scientific Expeditions 2016 and 2017 (BarrientosMuñoz and Ramirez-Gallego, 2016; Ramirez-Gallego and Barrientos-Muñoz, 2017). The following 10 fields are included per species within this dataset:

Scientific Name ID: These fields include a unique and stable-through-time alphanumeric identifier (taxonomic identifier) AphiaID provided by World Register of Marine Species (WoRMS).

Basis of record: As the data set includes records based on direct observation in the field or indirect observations (photos), this field contains this specific information for each species.

Institution Code: This field includes the name (or acronym) in use by the institution having custody of the object(s) or information referred to in the record. 


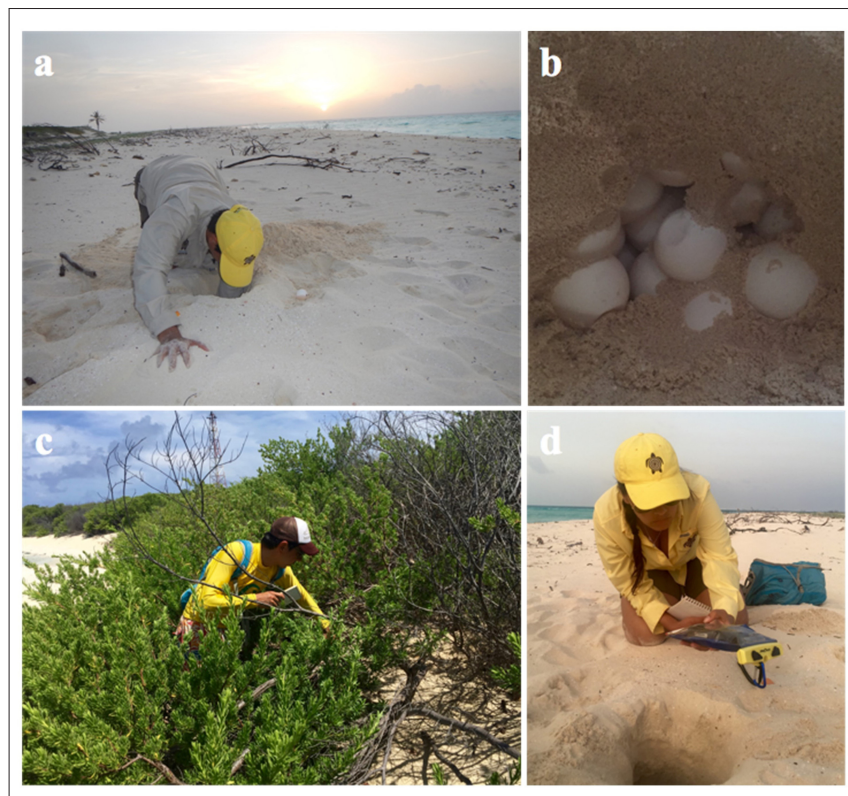

FIGURE 2 | Record of clutches and cleaning of hatched nests. (a) identification of loggerhead turtle nest in the middle and exposed area of the beach. (b) Confirmation of successful nests. (c) Identification of hawksbill turtle nest in vegetation zone. (d) Georeferencing and cleaning of hatched nests on Serrana Island (Photos: Karla Barrientos-Muñoz and Cristian Ramirez-Gallego, Fundación Tortugas del Mar).

Event Date: This field includes the date of biological events recorded.

Locality: Specific localities where the species have been recorded in the Serrana and Serranilla islands are presented in this field. Five localities were defined considering the Southwest Cay, Beacon Cay, Sand Cay, Middle Cay, and East Cay.

References: This field includes references that have compiled sea turtle species records during the Expeditions to SFBR in 2016 and 2017.

Life Stage: The age or life stage of the biological entity or entities at the time of the biological registration.

Reproductive Condition: Reproductive condition of the biological entity represented in the biological record.

Habitat: A category (beach of nesting or foraging site) of the habitat in which the event was registered.

Coordinates: Geographical latitude and geographic length (in decimal degrees, using the spatial reference system provided in Geodesic Datum) of the geographic center of a location.

\section{Distribution and Abundance of Sea Turtle Species}

In Southwest Cay, Serrana Island, three species were confirmed in the area: the loggerhead turtle (Caretta caretta), hawksbill turtle (Eretmochelys imbricata), and green turtle (Chelonia mydas). The loggerhead and hawksbill used beaches of Southwest Cay as nesting area with five and 20 nests, respectively (Figure 1; Table 1). Additionally, a hawksbill juvenile and a hawksbill male, as well as a green turtle juvenile were present in foraging areas around of Serrana Island. Meanwhile, at Serranilla Island, which included Beacon Cay, Sand Cay, Middle Cay, and East Cay, a total of 141 nests were confirmed for the green turtle, the hawksbill turtle, and loggerhead turtle (Figure 1; Table 1). Of the four keys evaluated, Cayo Beacon is the main site for sea turtle nesting in Serranilla, with $71.6 \%$ (101 nests) among the three species identified. For the green turtle (C. mydas), a total of 78 nests were documented, of which 63 nests $(80.8 \%)$ were spawned on the beaches of Beacon Cay, followed by six nests (7.7\%) spawned in Middle Cay. For the hawksbill turtle (E. imbricata), 58 nests were recorded, of which 35 nests $(60.3 \%)$ were spawned in Beacon Cay and 16 nests (27.6\%) in East Cay. For the loggerhead turtle (C. caretta), five nests were recorded, three nests $(60 \%)$ were spawned in Beacon Cay and two nests (40\%) in Sand Cay (see Figure 1). Furthermore, we confirmed that the marine habitats of Serranilla Island are used as feeding grounds by the presence of a hawksbill turtle juvenile captured meanwhile its was feeding sponges.

In the 1997 nesting season, McCormick reported nine hawksbill nests, four loggerhead turtles, and two green turtles nests in Serrana Island (McCormick, 1997). Nineteen years later in the Seaflower Expedition 2016, we confirmed the presence of nesting hawksbill and loggerhead sea turtle. Our monitoring effort was only 8 days (August 8-16), which may explain not having found any green turtle nest. However, green turtles have been observed in foraging areas around the island (Barrientos-Muñoz and Ramirez-Gallego, 2016). Also, Bruckner (2012) reported for Serrana Island and Bajo Nuevo, these three sea turtle species in marine habitats during the surveys of coral reefs.

The presence of five loggerhead turtles nests in Serrana and five nests in Serranilla with only a few days of effort and both at the end of the nesting season ( $\sim 4$ months, from May to August), is a sign that it is essential to implement monitoring, research, and long-term conservation actions with this species in the entire Seaflower Biosphere Reserve. These monitoring may be the greatest opportunity to recover loggerhead turtle populations in Colombia, where in the continental area are on board a local extinction (Páez et al., 2015a). The nesting populations of this species in the continental area of Colombia (departments of Magdalena and La Guajira) is restricted to no more than a dozen nests per year (Moreno-Munar et al., 2014; Merizalde, 2017). For the critically endangered hawksbill turtle (Barrientos-Muñoz et al., 2015), Beacon Cay in Serranilla Island together with Southwest Cay in Serrana Island, represent the most conserved places for nesting in Colombia. This is because the hawksbill turtle prefer the vegetation zone for nesting, which is covered mainly by the shade of the coastal and native Caribbean plant Suriana maritima that was predominant in both keys (Figure 2c). The high presence of S. maritima in Beacon Cay, its good development and state of conservation around the whole cay, protects the nests from coastal erosion. Therefore Beacon Cay is the main nesting site in the Colombian Caribbean for the endangered green turtle (Páez et al., 2015b). Although this species prefers to nest in the middle zone of the beach profile, a high percentage of the nests of this species were laid 
TABLE 1 | Inventory of three sea turtle species (Caretta caretta, Chelonia mydas, and Eretmochelys imbricata) in different life stages (eggs and nesting females at the sandy beaches, juveniles, and adults at the sea) in Serrana Island and Serranilla Island during the Seaflower Expeditions 2016 and 2017 in the Colombian Caribbean.

\begin{tabular}{|c|c|c|c|c|c|c|}
\hline \multirow[t]{2}{*}{ Life stage } & \multirow[t]{2}{*}{ Scientific name } & \multicolumn{5}{|c|}{ Location } \\
\hline & & $\begin{array}{l}\text { Serrana Island } \\
\text { Southwest Cay }\end{array}$ & Beacon Cay & Sand Cay & Middle Cay & East Cay \\
\hline \multirow[t]{3}{*}{ Eggs (Nests) } & Caretta caretta & 5 & 3 & 2 & 0 & 0 \\
\hline & Chelonia mydas & 0 & 63 & 4 & 6 & 5 \\
\hline & Reference & 1 & 2 & 2 & 2 & 2 \\
\hline \multirow[t]{4}{*}{ Nesting females } & Caretta caretta & 1 & 0 & & & \\
\hline & Chelonia mydas & 0 & 2 & & & \\
\hline & Eretmochelys imbricata & 0 & 2 & & & \\
\hline & Total of nesting females & 1 & 4 & & & \\
\hline \multirow{2}{*}{ Juveniles } & Total juveniles & 2 & 1 & & & \\
\hline & Reference & 1 & 2 & & & \\
\hline \multirow[t]{5}{*}{ Adults } & Caretta caretta & 0 & 0 & & & \\
\hline & Chelonia mydas & 0 & 0 & & & \\
\hline & Eretmochelys imbricata & 1 & 0 & & & \\
\hline & Total adults & 1 & 0 & & & \\
\hline & Reference & 1 & 2 & & & \\
\hline
\end{tabular}

Reference 1 corresponds to Barrientos-Muñoz and Ramirez-Gallego (2016), and the reference 2 corresponds to Ramirez-Gallego and Barrientos-Muñoz (2017).

in the vegetation zone, under the shadow of S. maritima and Conocarpus erectus.

\section{SFBR Is Synonymous of Hope for the Recovery and Conservation of Sea Turtles}

Our records indicated that Serranilla Island is currently the main nesting site for the green turtle. Serrana and Serranilla are possibly the most important nesting sites for the hawksbill turtle in the Colombian Caribbean. Southwest Cay (Serrana Island), Beacon Cay, and Sand Cay (Serranilla Island) are currently the main nesting sites for the loggerhead turtle in the Colombian Caribbean. This represents a hope for this species with greater probability of local extinction in Colombia. The significant presence of loggerheads observed in these cays indicates the importance that SFBR represent for the survival of this species in the Caribbean. However, it is necessary to carry out a complete monitoring in all the cays of the SFBR to determine nesting trends by these three species. Our results are a valuable contribution to knowledge regarding the presence of reproductive and foraging sites for three sea turtle species, and demonstrate the relevance of implementing a long-term monitoring and research studies of these nesting colonies in the SFBR. These studies should strengthen the management of these species, which will contribute to the recovery of sea turtles population in the region.

\section{DATA AVAILABILITY STATEMENT}

The dataset Sea turtles at the Serrana Island and Serranilla Island, Seaflower Biosphere Reserve, Colombian Caribbean, was assembled using the Darwin Core standard $(\mathrm{DwC})$ and is available through the Integrated Publishing Tool of the OBIS and the Global Biodiversity Information Facility (GBIF) Colombian nodes (SIBM -SIB Colombia) (IPT link: https://ipt.biodiversidad. $\mathrm{co} / \mathrm{sib} / \mathrm{resource} ? \mathrm{r}=\mathrm{ftm} \_$tortugas_seaflower_2016, https://ipt. biodiversidad.co/sib/resource? $\mathrm{r}=\mathrm{ftm} \_t$ tortugas_seaflower_2017; GBIF Portal: https://www.gbif.org/dataset/44c28cce-f455-4002b6d3-96ccdd30e8b3, https://www.gbif.org/dataset/29e92c92eee8-49f6-a43d-907cc37027d1; DOI: https://doi.org/10.15472/ p9w6sj, https://doi.org/10.15472/tjc0hg).

\section{ETHICS STATEMENT}

Ethical review and approval was not required for the animal study because this article was based solely on the registration of sea turtles in nesting and foraging areas. There was no collection of individuals.

\section{AUTHOR CONTRIBUTIONS}

CR-G and KB-M collected and identified sea turtle species during expeditions to Serrana and Serranilla Islands (2016 and 
2017), collected and processed the information for the biological records and the checklist dataset, compiled the complete checklist dataset, performed the descriptive analyses, wrote the manuscript, and reviewed and approved the manuscript.

\section{FUNDING}

This work was possible thanks to funding from Fundación Tortugas del Mar, Comisión Colombiana del Océano through Colombia Bio-Colciencias project (agreement No. 341 of 2017), the National Navy Armada República Colombia, Dirección General Marítima-DIMAR, Governorate of the Archipiélago de San Andrés, Providencia y Santa Catalina, Universidad de los Andes, CORALINA, National Oceanic and Atmospheric

\section{REFERENCES}

Barrientos-Muñoz, K. G., Páez, V. P., and Ramirez-Gallego, C. (2015). “Tortugacarey. Eretmochelys imbricata (Linnaeus, 1766)," in Libro rojo de reptiles de Colombia (2015), eds M. A. Morales- Betancourt, C. A. Lasso, V. P. Páez, and B. Bock (Bogotá: Instituto de Investigación de Recursos Biológicos Alexander von Humboldt (IAvH), Universidad de Antioquia), 127-131.

Barrientos-Muñoz, K. G., and Ramirez-Gallego, C. (2016). Tortugas marinas de la Isla Cayo Serrana durante la Expedición Seaflower 2016 - Proyecto Colombia BIO. Version 2.2. Fundación Tortugas del Mar. Ocurrence dataset. doi: $10.15472 / \mathrm{p} 9 \mathrm{w} 6 \mathrm{sj}$

Bruckner, A. (2012). Global Reef Expedition: San Andres Archipelago, Colombia. Field Report. April 9-24, 2012. Khaled bin Sultan Living Oceans Foundation, Landover, MD, Unite States, 52.

CORALINA-INVEMAR. (2012). "Atlas de la reserva de Biósfera Seaflower. Archipiélago de San Andrés, providencia y Santa Catalina," in Serie de Publicaciones Especiales de INVEMAR No. 28, eds D. I. Gómez-López, C. Segura-Quintero, P. C. Sierra-Correa, and J. Garay-Tinoco (Santa Marta: Instituto de Investigaciones Marinas y Costeras “José Benito Vives De Andréis"INVEMAR y Corporación para el Desarrollo Sostenible del Archipiélago de San Andrés, Providencia y Santa Catalina-CORALINA). Available online at: http:// www.invemar.org.co/redcosteral/invemar/docs/10447AtlasSAISeaflower.pdf

Diaz, A., and Andrade, C. (2011). Variación de la línea de costa en Cayo Serrana y estrategias para su conservación ante las amenazas de origen natural. Boletín Científico CIOH 72-86.

Garcilaso de la Vega (1609). Comentarios Reales de los Incas, Tomo I. Edición, índice analítico y glosario de Carlos Araníbar. Lima: Fondo de Cultura Económica Colección Historia, 1991, Libro Primero, Capítulos VII-VIII, 23-28.

González, S. J., and Pardo, Y. (2017). Expedición Seaflower - Isla Cayo Serranilla, 2017. Dirección General Marítima-DIMAR. Available online at: http://arcg.is/ 19 HXSn

McCormick, C. C. (1997). "Porque ellas también tienen derecho a seguir dejando huella," in Diagnóstico actual de las tortugas marinas del archipiélago de San Andrés, Providencia y Santa Catalina, Fase II (San Andrés: CORALINA), 67.

McCormick, C. C. (1998). Diagnóstico actual de las tortugas marinas del archipiélago de San Andrés, Providencia y Santa Catalina. San Andrés: CORALINA, 41 .
Administration-NOAA, The Ocean Foundation, and the Archie Carr Center for Sea Turtle Research.

\section{ACKNOWLEDGMENTS}

We thank the institutions and people who organized and participated in SeaFlower Expeditions. Thanks to ARC Providencia crew, ARC 20 de Julio crew, and ARC Roncador crew. Special thanks to T. Forbes, J. Paramo, and D. Cardeñosa, who support the inventories with some photographic records or hand capture of sea turtles in -water. Also thank to J. Leal, $\mathrm{N}$. Bolaños, and R. Vazquez, who were crucial in the process of data collection, and D. Morales, who helped with the nesting sea turtle maps.

Merizalde, L. A. (2017). Informe Final Año 2017, Alianza Interinstitucional para el manejo, la conservación y el desarrollo sostenible de la Guajira (Fase VI). Bogotá: Programa conservación para el desarrollo Alianza Fondo Acción Conservación Internacional Colombia, 38.

Morales-Betancourt, M. A., Lasso, C. A., Páez, V. P., and Bock, B. (eds.). (2015). Libro rojo de reptiles de Colombia (2015). Bogotá: Instituto de Investigación de Recursos Biológicos Alexander von Humboldt (IAvH), Universidad de Antioquia.

Moreno-Munar, A. A., Ospina-Sanchez, S. C., Jauregui-Romero, G. A., and Alvarez, R. (2014). Monitoreamiento de poblaciones de tortugas marinas en los sectores de Arrecifes y Cañaveral, Parque Nacional Natural Tayrona, Colombia. Arq. Cien. Mar. Fortaleza 47, 19-30. Available online at: http://www. repositorio.ufc.br/bitstream/riufc/28712/1/2014_art_aammunar.pdf

Páez, V. P., Ramirez-Gallego, C., and Barrientos-Muñoz, K. G. (2015a). “Tortuga caguama. Careta caretta (Linnaeus, 1758)," in Libro rojo de reptiles de Colombia (2015), eds M. A. Morales-Betancourt, C. A. Lasso, V. P. Páez, and B. Bock (Bogotá: Instituto de Investigación de Recursos Biológicos Alexander von Humboldt (IAvH), Universidad de Antioquia), 118-121.

Páez, V. P., Ramirez-Gallego, C., and Barrientos-Muñoz, K. G. (2015b). “Tortuga verde. Chelonia mydas (Linnaeus, 1758)," in Libro rojo de reptiles de Colombia (2015), eds M. A. Morales-Betancourt, C. A. Lasso, V. P. Páez, and B. Bock (Bogotá: Instituto de Investigación de Recursos Biológicos Alexander von Humboldt (IAvH), Universidad de Antioquia), 153-156.

Ramirez-Gallego, C., and Barrientos-Muñoz, K. G. (2017). Tortugas marinas de la Isla Cayos de Serranilla durante la Expedición Seaflower 2017 - Proyecto Colombia BIO. Version 3.1. Fundación Tortugas del Mar. Ocurrence dataset. doi: $10.15472 /$ tjcohg

Conflict of Interest: The authors declare that the research was conducted in the absence of any commercial or financial relationships that could be construed as a potential conflict of interest.

Copyright (c) 2020 Ramirez-Gallego and Barrientos-Muñoz. This is an open-access article distributed under the terms of the Creative Commons Attribution License (CC $B Y)$. The use, distribution or reproduction in other forums is permitted, provided the original author(s) and the copyright owner(s) are credited and that the original publication in this journal is cited, in accordance with accepted academic practice. No use, distribution or reproduction is permitted which does not comply with these terms. 